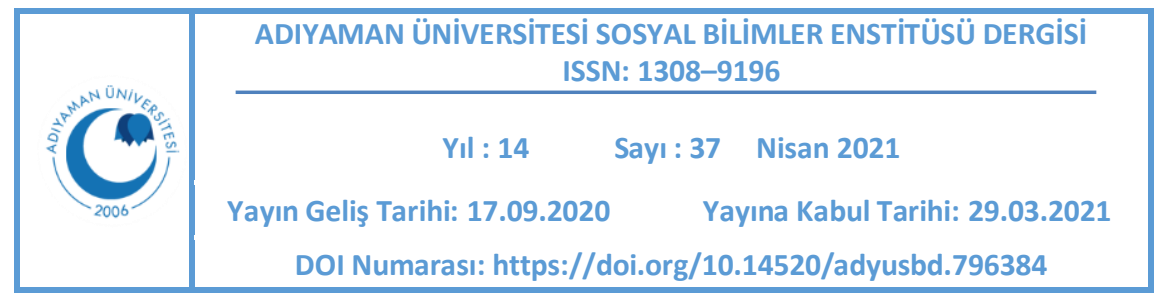

\title{
COERCIVE EXTERNALITIES IN DECISION-MAKING PROCESSES: IS IT POSSIBLE MIGRATION POLICY FOR TURKEY?
}

\begin{abstract}
Özkan DURNA*
Abstract

This article claims that national migration policies are limited by some externalities. These limitations are so powerful that they do not nearly let national governments decision-making about migration policies. In the last decade, Turkey, struggling with enormous immigration inflows, is the most obvious example of this situation. On one side, some international organizations forcing Turkey to be their policy instrument, and on the other side, Turkey tries to keeping some tenets like humanitarian diplomacy policy and some human rights agreements. In addition to these restrictions, there are others already accepted in the literature of decision-making on public policy. In conclusion, the article is dissolving whether Turkey's making migration policy with descriptive method is possible or not and under coercive externalities, it reaches that is difficult to design a rational migrant policy.
\end{abstract}

Keywords: Migration policy, coercive externalities, Turkey, decisionmaking.

Araştırma Görevlisi, Mersin Üniversitesi İktisadi ve İdari Bilimler Fakültesi Kamu Yönetimi Bölümü, ozkandurna@mersin.edu.tr ORCID: https://orcid.org/0000-0003-13860950 


\title{
KARAR ALMA SÜREÇLERINDEKI DIŞSAL ZORLAYICILAR: TÜRKIYE IÇIN GÖÇ POLITIKASI MÜMKÜN MÜ?
}

$\ddot{O} z$

\begin{abstract}
Bu makale, ulusal göç politikalarının bazı dısssallıklar tarafından sınırlandırıldığını iddia ediyor. Bu sınırlııklar o kadar güçlü ki, ulusal hükümetlerin göç politikasına karar vermesine bile neredeyse imkân tanımıyor. Son on yıldır muazzam bir göç akışıla mücadele eden Türkiye, bu durumun en açık örneğidir. Bir yandan uluslararası kuruluşlar Türkiye'yi politikalarının bir aracı olmaya zorlarken, diğer taraftan Türkiye insancıl diplomasi ve insan hakları antlaşmaları gibi bazı ilkeleri ve insan hakları antlaşmalarını sürdürmeye çalışıyor. Bu sınırlılıklara ilaveten, karar verme literatüründe halihazırda kabul edilen sınırlııklar var. Sonuç olarak, makale Türkiye'nin göç politikası yapımınının mümkün olup olmadığını betimsel yöntemle çözümlüyor ve bu sınırlılıklar altında rasyonel göç politikası yapmanın zor olduğu sonucuna ulaşmaktadır.
\end{abstract}

Anahtar Kelimeler: Göç politikası, zorlayıcı dısssallıklar, Türkiye, karar verme.

\section{INTRODUCTION}

Today, we are living in an era of migrations. Most of our national states somehow include minorities and a lot of immigrants. Peoples keeping flow on both internal and external areas and it doesn't seem end near future. There are plenty of theories, which explain why migrations realize. Some of them focus on economic, environmental and demographic reasons for migrations and others describe migrations as a conclusion of historical-structural perspectives. The common feature of these theories is related to equilibrium. According to the historical-structural perspective, economic and political powers are not equally distributed, so different countries highly unequal access to resources. The capitalist economic model supports these unplanned economic chaoses for cheap laboring force (Castles, De Haas and Miller, 2013: 28-36). Within globalization, unequal circumstances trigger endless migrations. 
Endless migrations have made not only migration policies but also migrationrelated policies more important. Endless migrations cause endless reforms on policies. Migration policies are defined as an establishment in order to affect behavior of a target population (potential migrants) in an intended direction (Czaika, M., \& De Haas, 2013: 489). Border controls and visa applications are the first devices for realizing this aim. In addition to these first devices, residence and working permissions are the other important devices. Actually, some scholars differ the immigrant and alienage policies. This classification is based on the competencies determined by the legal system. So, it is a functional distinction in migration policies (Filindra, 2019: 501). In this study, migration policies are held as a whole, even immigration-related policies are included in that definition.

Migration policies are quite broad. For this reason, some scholars debate migration policies whether public policy or not. Anderson (2003: 2) defines public policy as a relatively stable, purposive course of action followed by an actor or set of actors in dealing with a problem or matter of concern. According to the definition, public policies have four features: first, becoming relatively stable; second, purposive actions; third, to make and follow a set of actors; the last one is related to a problem. Migration policies even contain lots of different concerns and problems, on the basic, they plan to affect foreigner's attitudes. So, it should be said that migration policies are public policies (Filindra, 2019: 500). Since migration policies are public policy, it could be analyzed with public policy's theories, phenomenons, and other paradigms. In this way, we could understand migration policies' effectiveness, possibilities, conclusions more easily. But firstly, it should be shown what migration policies' extent, because it is related to lots of public policy. Scope of this article, every policy about the 
Turkey?

migration adopted as migration policy. So even, migration-related policies regarded as migration policy, even though other policies' competences are so different. In this way, not only visa, border controls and legal statue of foreigners are migration policies, but also health, education, laboring forces related policies are migration policies. Although, it is nearly impossible to see this all fields on a single paper, thanks to some tenets or aims we could create or evaluate the migration policies.

Today's national states are mostly deciding their public policies by themselves. They could specify rigid or soft migration policies. But sometimes, they could hesitate about it; because free marketing systems always want to cheap laboring power but on the other side, states could be unwilling to accept immigrants because of sustainable wealth. This is a really important dilemma of wealthy and welfare states. Separately, it is difficult to make a balance on acceptance of immigrants and other factors make the process more complicated. The abovementioned about migration policies' aim is to affect to potential immigrants, but every state aims it. For this reason, states' rigid migration policies affect other states. It is called a substitution effect in the literature (Czaika, M., \& De Haas, H., 2013: 497). Taking account of that effect made migration policies more complicated. This effect is actually unintended effects on other migration flows. It could be on four different ways: 1) spatial substitution through the diversion of migration to other countries; 2) categorical substitution through a reorientation toward other legal or illegal channels of immigration; 3 ) inter-temporal substitution affecting the timing of migration, such as "now or never migration" in the expectation of future tightening of policies; and 4) reverse flow substitution if immigration restrictions reduce not only inflows but also return migration, which can make the effects on net immigration rather ambiguous (Czaika, M., \& De Haas, H., 2013: 497). Besides them, some international treaties or tenets are very 
important while preparing migration policies. Some of these international sources like Convention Relating to the Status of Refugees which has also known as a 1951 Refugee Convention or European Convention on Human Rights have binding forces and others like 1948 Universal Declaration of Human Rights are just important as tenets.

In the light of these explanations, in this article examines Turkey's coercive externalities about migration policies in the last decade. After the unrest in Syria in 2011 caused great inflows towards other countries. Turkey one of the most affected countries by these inflows. According to Directorate General of Migration Management's (DGMM) numbers, today, 3.7 million Syrian people are living in Turkey on a statue of temporary protection (goc.gov.tr, 2019*). Turkey's Syrian migration policy based on the temporariness. They supposed that these people would turn back their home soon, but Syria's civil war still remain and it seems not to end near future. For this reason, Turkey should prepare detailed migration policies. However, Turkey has great difficulties: first, numbers of Syrian immigrants still increase and nobody knows what happens near future. Secondly, the number of immigrants is transcending Turkey's facilities for humanitarian living conditions. For most immigrants, Turkey is a transit country for going to western countries, but because of European countries' rigid border policies, Turkey is transforming as a target country. For this reason, Turkey is both a transit and target country. In addition, Turkey is a part of Convention Relating to the Status of Refugees, they couldn't expel or return in case of their life or freedom in danger because of race, religion, nationality, membership of a particular social group or political opinion.

In this article is dissolving Turkey's possibilities about migration policymaking under coercive externalities. These externalities are separated into three main

\footnotetext{
${ }^{*}$ https://www.goc.gov.tr/gecici-koruma5638 (Last Access: 30.10.2019).
} 
Turkey?

sections. First is caused by its treaties, conventions, and tenets of international law. International law affects countries not only binding forces but also some phenomenons like humanitarian diplomacy. The second section is Turkey's relationships with different international organizations. This institutional section explains Turkey's position in the migrations world. These international organizations limited in this study with European Union (EU), United Nations High Commisseniors for Refugees (UNHCR) and International Organization for Migration (IOM). EU is important for being the most common target countries for all migrations and of course for Syrian migrations. So, their policies related to migrations deeply affect Turkey as a border neighbor of them. United Nations is really important especially on funding for humanitarian aids. UNHCR is a global refugee agency whose aim saving lives, protecting rights and building a better future for refugees, forcibly displaced communities and stateless people (UNHCR, 2019). Besides UNHCR, IOM wants to exact and swift solution for migration problems. For this reason, they want immediate integration of immigrants in which they are living. But Turkey is not sure having the opportunity for all Syrian immigrants living in Turkey. Third section is interested in decision-making which in ambiguous circumstances. One of the most important elements of decision-making on public policies is knowledge about the subjects. The more actors know about the subject, the easier to find a solution for the public problem. But for the migration policies to know detailed processes to motivate potential migrants to move or to guess what happens middle future is really difficult. So, deciding on public policies related to migrants made the process more complicated. For Turkey, Ambiguity ambiance is not just related to only bloody conflict, it is also up to some target countries' migration policies. 
Before these three topics, the article starts with a section defining migration. In this section, it will be mentioned not only the definition of migration, also Turkey's narrative about migrations in the last decade. The main sources of the article are international treaties, agreements, governmental papers, policy papers, the legal systems of Turkey related migration, activity reports of some international and national institutions, academic books and articles related to the migration policy of Turkey. With descriptive method, the article reaches a conclusion about Turkey's pros and cons for migration policies and reply to the question of whether it is possible to decision making on migration policies with coercive externalities or not.

\section{MEANING OF MIGRATION FOR TURKEY}

Briefly, the meaning of migration is moving from a place to another place for temporary or permanent time. It doesn't matter whether it is temporary or permanent, it has always a deep effect sociologically and politically. This movement could be in a country or it could transcend the border. If it doesn't transcend the borders named internal migration, but if it transcends, named external migration. At the migration studies, the reasons caused migration are varied but it is generally explained by economic theories. A most common model explaining migration is push-pull factors. According to this model, some reasons push people to move and, at the target places, some reasons pull them. Population growth, lack of economic opportunity, political repression are some of the push factors. Demand for labor, availability of the land, economic opportunities, and political freedoms are some pull factors (Castles, De Haas and Miller, 2013: 28). Push-pull model isn't just economical, it's also demographic and environmental. 
Turkey?

Historical-structural theories are also important for explaining migrations. According to this theory, political and economic power is unequally distributed among wealthy and poor countries. For this reason, peoples' opportunities are the varied and capitalist economic model reinforces the unequal situation (Castles, De Haas and Miller, 2013: 32). So, it is a very critical phenomenon for every country, regardless of which theory is taken into consideration. Migration as a phenomenon is not new. However, it has never been as pervasive, or as socio-economically and politically significant, as it is today. Never before have political leaders accorded such priority to migration concerns (Castles, De Haas and Miller, 2013: 317). For this reason, migration policies are always the leading agenda of nearly every country. If we think of other policies related to migratory processes, we could more easily understand its enormous effect on policy formulation. Migration policies differ from other policies in terms of object and subject. Other public policies formulate subject but on migration policies, immigrants are both subject and object. Natter (2018: 13-16) says that some problems about migration policy aren't peculiar to democratic or developed countries. It is also the same problem with other countries. So in this perspective, it could be said that migration policies are transcending political systems in this way. The important one is the state's structure, functioning, and practices instead of autocracy and democracy. We should give up thinking states as homogenizing while formulating migration policies and realize internal fragmentations of policy actors.

Turkey experienced both immigrations and emigrations in the near past. The reasons having come to Turkey for international protection are generally political conflict or wars. Following the Revolution of 1979 , nearly one million people used Turkey for transit passing and 200000 of them stayed in Turkey. In 1989, more than 300000 people who are ethnically Turks have come to Turkey for asylum seekers from Bulgaria because of repressive regime and harsh 
assimilation policies imposed on them. In Bulgaria, the regime changed in 1990 and some of those asylum seekers turned back their country but nearly 200000 of them settled in Turkey. After the Iran-Iraq war, Turkey hosted 50000 people displaced by Iraqi military actions. In 1991, as the second wave of Iran-Iraq conflict, nearly 500000 people escaping from the Iraqi military entered Turkey. In 1992, after the outbreak of persecution in Bosnia-Herzegovina where a total of 20,000 Bosnians took shelter in Turkey between 1992 and 1998. Acceptance of Dayton Peace Agreement, most of them turn back, nearly 2000 stayed in Turkey and nearly 5000 obtained refugee status and migrated to Western countries. As a receiving country, collapse of the Soviet Union was also important for Turkey. They were hosted 17746 people in 1999 after the incidents in Kosovo and 10500 people in 2001 from Macedonia. Throughout the last decade, inflows continuing especially from Afghanistan, Pakistan, Iraq some other undeveloped countries. But the last massive inflow is still continuing. After ongoing conflicts and civil war in Syria, nearly 10 million people had to leave their home and almost 4 million of them are living in Turkey (mülteciler.org.tr, 2019). As the conflict in Syria escalates, Turkey continues to receive more people crossing its borders, with many settling in Turkey and many trying to reach Europe (Yıldız, 2016: 101-102).

Turkey, as an emigration country, has sent its nationals especially Western European countries with some bilateral agreements. These agreements generally dated the 1960s and 1970s. In this perspective, Turkey's emigration flows defined as labor migration. The first bilateral agreement to export migrant labor was signed with Germany in 1961, followed by similar agreements with Austria, the Netherlands and Belgium in 1964, France in 1965, Sweden and Australia in 1967, Switzerland in 1971, Denmark in 1973 and Norway in 1981. Turkish immigrants were thought to stay just for a while. Then they would turn back their countries with new skills and abilities. But these expectations haven't 
Turkey?

realized and most of them stayed their host countries. Today, with the reunification of families, asylum claims, Turkey has the highest population in Europe amongst the non-citizen population. After the 1973 oil crisis, labor migration flows from Turkey changed its routes towards Arab countries. Between 1967 and 1980, Turkish laborers emigrated to Saudi Arabia and Libya. Until 1992, new countries have been added that list: Kuwait, Iraq, Jordan, and Yemen. After the collapse of Soviet Union, Turkish workers went to these new destinations like Turkmenistan, Russia, Azerbaijan. In 2014, the top five destination countries of workers from Turkey were Russia, Iraq, Saudi Arabia, Turkmenistan, and Azerbaijan. Emigrations from Turkey was not only for economic reasons but also for political reasons. A lot of people migrated after the military convention in the early 1980s and separatist Kurdish movement in Turkey's southern caused emigration. According to UNHCR statistics, almost one million Turkish citizens applied for asylum in various European countries between 1980 and 2010. Today, migration, as a phenomenon, has not changed but rigid visa and border policies are changed immigrants' profiles from unskilled laborers to skilled laborers (Yıldız, 2016: 99).

\section{INTERNATIONAL LAW AS A COERCIVE POWER}

Policymakers have some limitations while formulating their policies. These limitations are derived from both national and international legal systems. Some other reasons that limit policymakers stem from some tenets like humanitarian diplomacy or good-faith as national, constitutions are the first papers that limit policymakers. Then, other laws regulate policymakers' attitudes and restrict their options.

International agreements could also restrict policymakers' decisions. These agreements could be bilateral or multilateral. Almost every circumstance, it is 
not important the number of participants for the agreements' validations and implementation as international affairs. But every agreement's effects aren't the same. Some of them have a bending force, but some others haven't. Lastly, some international sources are used just for principles those states could apply them like International Bill of Human Rights.

In this section, the most important international papers' effects will be discussed in terms of Turkey's migration policy formulating processes. For this subject, firstly, Convention Relating to the Status of Refugees, especially articles 32 and 33, will be evaluated. Convention relating to the Status of Refugees was adopted by United Nation in Geneva in 1951, but in Turkey, it has come into force after adopted by Grand National Assembly in 1961 with a reservation which is related not providing rights more than for Turkish nationals. The most important title lines are expulsion, refoulment, and naturalization with regards to making migration policy for Turkey. According to article 32, [t] he Contracting States shall not expel a refugee lawfully in their territory save on grounds of national security or public order. And the refugee should be allowed to clear himself and submit evidence, could have the possibility of the appeal of the decision. But there are some exceptions to these rights. Giving enough time to defend himself is could be abolished for compelling reasons of national security. In article 33, prohibition of expulsion or return, a refugee couldn't be sent or expel in any manner to the frontiers of territories where her/his life or freedom would be threatened on account of her/his race, religion, nationality, membership of a particular social group or political opinion. But if there are reasonable grounds for regarding as a danger to the security of the country, especially having been convicted by a final judgement of a particularly serious crime, the refugees couldn't claim rights of this article. 
These two articles supply important rights for refugees but mentioned exceptions, make possible for the contracting country to return refugees. The derogations are located the convention gives governments very critical discretion relating the migratory process. So, in this way, the rights given by the convention could be meaningless for asylum seekers. Discretions are not only for when it emerged, but it is also for the definition of the phenomenons like national security, public order or important crimes. Actually, the convention's intention for refugees is very important and it wants to supply rights for living in good conditions, we could understand this intention next article 33. Title line naturalization says that $[\mathrm{t}]$ he Contracting States shall as far as possible facilitate the assimilation and naturalization of refugees. They shall in particular make every effort to expedite naturalization proceedings and to reduce as far as possible the charges and costs of such proceedings. So, the convention wants to realize swiftly the integrations of refugees but with derogations omit its spirits.

1951 Convention was just protecting people who asking for refugee status relating to the events occurring before 1951. In 1967, United Nations have agreed on a supplementary protocol for the 1951 Convention. According to this protocol, time and geographical limitations have been abolished. Turkish Ministerial Cabinet has accepted this protocol but insisted on reservation relating to the geographical limitation.

Turkey also adopted International Covenant on Civil and Political Rights which entered into force by United Nations General Assembly in 1976. The rights proclaimed in covenant stem from the inherent dignity of human beings. So, it tries to build inalienable rights for everybody no matter their race, religion, ethnicity, or other belongings. For foreigners law, its thirteenth article is important. The clause is related to peoples living legally in different countries. According to the article, the states may only expel them in after decision which 
pursued in accordance with the law and allow to review the expel decision by competent authorities except for national security requirements.

European Convention on Human Rights is a paper of Council of Europe. It came into force in 1953. Turkey signed the convention in 1954 and accepted the individual application for the European Court of Human Rights in 1987. In this convention with additional protocols protect right to life, prohibition of torture, prohibition of slavery and forced labour, right to liberty and security, right to a fair trial, no punishment without law, right to an effective remedy, prohibition of discrimination, protection of property, right to education, prohibition of collective expulsion of aliens and some procedural safeguards relating to expulsion of aliens. This convention shall be applied as a territorial, not in accordance with nationals. So, Turkey has to apply these rights and prohibition on the sovereign base area and she couldn't discriminate people as a citizen and noncitizen. And there are some additional protections for foreigners in article 4 of the fourth protocol and the first article of seventh protocol. According to the fourth protocol, it prohibits of collective expulsion of aliens. Seventh protocol mentions procedural safeguards relating to the expulsion of aliens. This clause is very similar to thirteenth article of the International Convention on Civil and Political Rights. But opposite of it, with the European Court of Human Rights, this clause has an effective judicial review in case of violation. Protocol No. 7, article 1:

1. An alien lawfully resident in the territory of a State shall not be expelled therefrom except in pursuance of a decision reached in accordance with law and shall be allowed:

(a) to submit reasons against his expulsion,

(b) to have his case reviewed, and 
(c) to be represented for these purposes before the competent authority or a person or persons designated by that authority.

2. An alien may be expelled before the exercise of his rights under paragraph 1.(a), (b) and (c) of this Article, when such expulsion is necessary in the interests of public order or is grounded on reasons of national security.

This article supplies important protection for aliens lawfully resident in the contracting states; but, derogations give states very broad field to act, for this reason, it remains national states are the core actors relating human rights and they could determinate their rules without taking account into these protections.

While a state determines its policies, they have to follow some rules and have some limitations. The abovementioned conventions are binding papers and these are more effective for formulating public policies, but some others could affect but they don't have bending effect. Here, it will be mentioned about International Bill of Human Rights and a phenomenon that could shape the migration policies: humanitarian diplomacy. International Bill of Human Rights was proclaimed in 1948. It is one of the most important papers of human rights. It mentions about free borning and equality, the prohibition of discrimination, rights of life, liberty and security; prohibition of slavery, inhuman and cruel treatments; different rights relating justice and before the law, having a nationality, religious freedom, property right, freedom of association, right to asylum. The fourteenth article is really important for the law of foreigners. According to the article: [e]veryone has the right to seek and enjoy in other countries asylum from persecution. So, this Bill gives rights to everyone seeking for asylum in case of persecution. As is seen, seeking asylum is a fundamental 
human right nearly for 80 years and it always mentions every human rights paper. So, even if this bill doesn't have a binding effect but it shapes countries' policies especially the migration policies. Lastly, its universal feature helped it to be a very important reference for all countries.

Finally, it will be mentioned about humanitarian diplomacy and its possible effect on Turkey's migration policies. Diplomacy could separate two sections: "capital D" and "small D" diplomacy. First one is about professional diplomats' act. Diplomats work for ending conflict, negotiate agreements. "capital D" Diplomacy is formal and high-level. "Small D" diplomacy is opposite of the first definition. It is generally terrestrial and locates humanitarian sphere (Minear, 2007: 11-12). These different definitions could overlap. For example, negotiating in hot-war or after conflicts, humanitarian practitioners could play an important role in peace and serenity. For humanitarian diplomacy, there is no agreed definition of it and even different definitions contradict each other. It could be classified in three different ways: oxymoron, common-sense, necessary evil. According to the first definition, its actors are different and as a result of it, their subjects are different. Non-governmental humanitarian actors prioritize human life, but for the governmental actors, the important one is their countries' security. The common-sense definition requires broad cooperation for dealing with the problem. This could be possible just some circumstances such as earthquakes that all international community has the same sense. Necessary evil perspective says that the situations generally requiring humanitarian aids where conflicts are experienced. So, they could think about their safeties and act with that knowledge (Sadık and Zorba, 2017: 16-18). In this article, humanitarian diplomacy is designated as a perspective to prioritize human safety and to put up humanitarian conditions. If we handle humanitarian diplomacy with that perspective, it could be difficult to formulating migration policies for Turkey. Otherwise, if humanitarian diplomacy 
Turkey?

is accepted just associated with international organizations, it wouldn't affect Turkey by no means. While four million people are waiting for asylum, it doesn't seem easy if Turkey wants to solve migratory problems fairly.

\section{INSTITUTIONAL COERCIVE}

Today, there are a lot of general or sectoral international institutions, but we are still living an era in which nation-states are the pioneer. International institutions have a global or at least a regional perspective relating their foundation aims. They could make pressure on the nation-states relating their expertise and transnational problems. This pressure's intensity is up to the problem's globalization and expertise of those institutions. So, nation-states are feeling pressure from international institutions about migration policies. For this reason, it makes more difficult to decide on migration policies for Turkey. While making migration policies, Turkey generally works with UNHCR, IOM and EU. UNHCR and IOM are working for humanitarian aids and ensure that immigrants live in humanitarian conditions. They want to speed up the integration process for immigrants. EU wants to control immigration inflows towards European countries. They make pressure on Turkey to utilize her as a buffer zone.

It should be confessed that EU isn't a confederation. Sometimes, EU states could violate the EU's policies, for this reason, it shouldn't be considered EU without fragmentations. But in this article, it was disregarded these fragmentations. To taking under control migration flows towards Western countries is very critical for the EU, because one-third of the world's displaced persons whose number nearly 60 million are living EU's near abroad. These numbers are rising very swiftly and most of them living in hostile conditions. So they aren't satisfied with their situation (Parkes, 2017: 8). Because of high numbers, the EU has to create powerful buffer zones. According to İçduygu and 
Şimşek (2017: 85), until 2015, the international community hasn't been shown required solidarity for humanitarian responsibility for Syrian conflicts and when it became thread for the EU, they rushed for effective policies about it. Actually, it could be seen as a great dilemma about migration not for a lack of solidarity. Developed countries are supposed to accept immigrants because they are cheap laborers. On the other side, they don't want any migration inflows because it was thought to be harmful serenity and security. And now, they want to come through this dilemma with their border and remote control policies thanks to new phenomenons. Mobility is one of these phenomena. EU wants peoples who come voluntarily for working and after a while, they turn back their original countries with new skills and experiences. Thus, the EU going on using cheap labor and get rid of unwanted immigrations (Parkes, 2017: 26).

Border control was the main interest of the EU's border policies last six decades (Parkes, 2017: 29). But it has changed for effective struggle irregular migrations. EU offers policies only for candidate countries but now they try to affect some other countries' public policies. It is very difficult to fight against reasons which cause migration. This kind of campaign named "root causing policies". But it has a lot of side effects. First, root causing could backfire by boosting the consensus to xenophobic and anti-EU movements. These countries which EU wants to affect the policies are not stable liberal democratic countries. In addition, it could produce more dependencies for the EU and they could easily be threatened by other countries. For example, EU-Africa Summit in late 2015, West African representatives delivered a stark warning to Brussels: migration is your problem, not ours (Parkes, 2017: 145). On the other side, being interested in root causing takes in not only the Middle East, and also nearly all African continent. And it doesn't match the EU's raison d'être and present structure (Pastore, 2017:47-49). 
Increasing migration inflows and EU's migration policies make immigrants political objects. Thus, anti-immigrant movements start rising. The discourse of anti-immigrant movements stems from three different topics. Firstly, economic reasons are leading these movements. The immigrants are more easily accept low prices, so, it is being considered to damage the economical order of the EU's countries. Secondly, it is always alleged that immigrants negatively affect social cohesion and cultural values by anti-migration movements. The last one is related to security arguments. Anti-immigration movements claim that migration inflows increase risks of terrorism, organized crimes, and individual criminal rates (Pastore, 2017: 16).

For the best way hindering irregular immigration is remote control policies at EU acquis. Turkey, as a candidate country, wants to fasten the membership process. Thus, the EU's policy suggestion on Turkey could be easily seen as a membership dialogue and the EU's presence reason (raison d'être) wouldn't be damaged. At the same time, Turkey isn't a member of the EU, so Turkey would be an effective buffer zone against immigration inflows for the EU. Turkey isn't the only country that signed a Readmission Agreement with the EU. Montenegro and Serbia are also the candidate and also signed the Readmission Agreements. These agreements have almost identical article headings including commonality of provisions with minor differences. Each Agreement starts with a Council Decision with an exceptional Explanatory Memorandum involving Political Legal Framework, Outcome of the Negotiations, and Conclusions sections for each country (Sönmez ve Kıvrım, 2017: 7). Actually, the Readmission Agreement isn't a new phenomenon for both sides. Between EU and Turkey, negotiations for Readmission Agreement have started in 2004 and draft agreement text has prepared in 2010. This text was prepared by EU Justice 
and Home Affairs Council and then Turkey has objected to enhance cooperation on migration, visa, and mobility issues. In 2011, Turkey insisted on agreement including a roadmap of visa liberation for Turkish nationals. Finally, the Readmission Agreement was signed on 16 December 2013 and came into force on 1 October 2014. The reason why it took so much time for agreement is concerning the acceptance of transit passes and readmission of third-country nationals. It could be an important burden and responsibility for Turkey (Sönmez ve Kıvrım, 2017: 10-11).

According to fourth article of the agreement, if a third-country national or stateless person has a valid visa for Turkey when they have come directly to the Member States or residence permit, they shall be readmitted by the Turkish side. Even though they don't have a legal document given by Turkish authorities, if they had passed the Member States by using the territory of Turkey, a third-country national or stateless person shall be readmitted by Turkish authorities. But if they have only been in airside transit via an international airport of Turkey or they already enjoy visa-free access or they have come to Turkey from the Member States, this ruling shall not be applied. According to the sixth article, nationals or persons already have a valid residence permit of the Member States shall be readmitted by the EU and this obligation also includes third nationals coming from the Member States to Turkey.

Readmission agreement between EU and Turkey was criticized by some academics by means of 1951 Convention relating to the Status of Refugees. Sentence of prohibition of expulsion or return prohibits expelling or returning a refugee to territories where she or he could be threatened her or his life or freedom. In Turkey, nearly four million Syrian are living there under the status of international protection and their living conditions, from laboring forces to 
Turkey?

education, are not well. Taking into consideration their living conditions, readmission of new refugees to Turkey could be commented as a violation of the Convention (Bozkurt, 2016: 405).

After this agreement, Turkey undertakes more responsibility relating to Syrian immigrants, although she couldn't submit humanitarian conditions for current immigrants. But in terms of the EU, this agreement made Turkey a powerful buffer zone.

UNHCR was established after World War II as a subsidiary organ of United Nations General Assembly. UNHCR is a global refugee agency whose aim saving lives, protecting rights and building a better future for refugees, forcibly displaced communities and stateless people (UNHCR, 2019 ${ }^{\dagger}$ ). And also, they induce countries for accepting international agreements or entitling new ones relating to refugees or stateless people. To realizing these aims, their conventional liabilities stem from 1951 The Refugee Convention (Uzun, 2016: 76-78). On UNHCR's Strategic Directions: 2017-2021, they mention what they want to do: protect, respond, include, empower and solve. Firstly, they want to protect the refugees against cruel actions and then respond to refugees' urgent versatile needs. After they want to integrate into the community where they live. This integration's meaning called by UNHCR as "include". As for empowering is relating accountability, increasing all range of administrative construction and "solve" refers to engage with the peace process or family unification (UNHCR, 2017). Even if they haven't custody for states (Uzun, 2016: 83) but being the leading organization for the refugee rights and conditions, they could make pressure on the states thanks to creating the refugee agenda on the international refugee.

${ }^{\dagger}$ https://www.unhcr.org/about-us.html (Last Access: 12.12.2019). 
IOM is another important actor preparing migration policies. It was founded in 1951 and today has more than 170 member states. Today they work on migration and development, facilitating, regulating and forced migration. But their activities cut across these areas include the promotion of international migration law, policy debate and guidance, protection of migrants' rights, migration health and the gender dimension of migration (IOM, 2019). IOM is one of the parts of UN but its bond does not tide as much as UNHCR. For this reason, it has strong mobility and this organization chart contributes to it as freedom and diversity on the activities. Its relative freedom makes a stakeholder of governments easier than other international organizations. And, of course, its powerful funds effective on being a stakeholder. Only in 2018, the Turkish Office of IOM has the budget 148 million dollars for over 50 projects in the field of supporting migrations, transfrontier intervention for North Syria, migration administration, and relocation (IOM, 2018: 8).

Even if their main mission was urgent humanitarian aid, they are really effective on nearly every subject relating to migratory. Turkey introduced IOM after the Gulf War in 1991 for helping people escaping from conflicts and be a member of it in 2004. Thus, IOM has helped Turkey when she needs humanitarian aid. But now, IOM is more than a humanitarian helper, which guides Turkey for the legal system and also public administration of Turkey especially empowering DGMM's structure (IOM, 2018: 8). IOM's multi-dimensional activities and formation made it an institutional partner of Turkey. Institutional partner is more than a stakeholder. Stakeholder refers to cooperation only a topic that takes for a while. After Turkey adopted IOM's legal infrastructure relating to law on foreigners and international protection and close cooperation with DGMM, IOM became a very important actor deciding on migration policies with their important budget. 


\section{AMBIGUITY ON DECISION-MAKING}

Formulating public policy requires multidimensional researches. After this researches, policy actors could make alternative ways for a solution. Then, it's time for choosing one of the alternative ways named decision-making. Some different theories could explain decision-making. The main phenomenon of these theories is knowledge. Rational theory connotes that public policy actors decide on policies after had all knowledge about the public problem. Incrementalism explains decision-making on public policy as a process. From this perspective, public policies are subsequent to old ones. This theory maintains the status quo and isn't innovative. It envisages little changes in previous public policies. These are the main pillars of decision-making; but amongst these two pillars, there are a lot of models that explain decisionmaking on public policy. "A third approach" is one of them. According to Etzioni (1967: 390) the best way to decide on policy is a mixture of rationalist and incrementalist theories. From this perspective, muddling through includes rationalist theory's innovation and taking lessons from old ones like incrementalists. Garbage can model is comparatively new and has a chaotic perspective. According to this model all problems and solutions put at the same place named garbage can because of not classified on different topics. This model is an organizational theory that is also valid in public policy theories. Other public policy theories have seen formulating public policy as a process, but according to garbage can model, it is chaotic and hasn't a specific ranking for formulating it.

Migration policies could be evaluated with these perspectives. Today, Turkey hosted nearly four million people looking for asylum. All of these people flew to Turkey in the last decade. So, these numbers show the importance of migration policy for Turkey. Most of this number is from Syria because of the bloody 
conflict and it still continues that conflict and nobody knows when it finishes. This ambiguity makes migration policy formulating more difficult. According to Turkey legal system, Syrian peoples escaped conflicts are in temporary protection and they couldn't be a refugee in Turkey because of geographical limitations. According to Law on Foreigners and International Protection, Turkey accepts refugees from the member states of the Council of Europe. Turkey is one of a few countries that use geographical limitations with Kongo, Madagascar, and Monaco (Erdoğan, 2018: 8). It is nearly a decade, they are living in Turkey, but they don't know what's going to be in the near future. Most of them haven't enough legal protection living and settling Turkey. Some of them don't want to live in Turkey, they think Turkey as a transit country and want to go to western countries. For this reason, Western countries' migration policies are really important in shaping Turkey's migration policies. Until now, in Turkey, was born more than three hundred thousand Syrian babies and they haven't Turkish citizenship and also Syrian one. Now, these babies risk being stateless.

\section{CONCLUSION}

Today, 4 million immigrants are living in Turkey. A great majority of them are from Syria and then Afghanistan and Iraq. 3.6 million people are from Syria, 170 thousand people are from Afghanistan and 142 thousand people are from Iraq (UNHCR, 2019). These numbers made Turkey having the highest number of immigrants all around the world (IOM, 2018: 12). Undoubtedly, nobody wants to leave their home without reason. These peoples had to leave their home countries because of war or great poverties.

This article is searched for the possibility of Turkey's migration policy while there were a lot of externalities affecting migration policies. Beginning of 2011, there is nobody in Turkey under temporary protection, but now more than 3.5 
million people had come to Turkey. These numbers show how great inflows emerged towards Turkey. So, for the migration policies, there is an emergency. For this reason, the main actor for supplying Syrian people humanitarian aids was Disaster and Emergency Management Presidency (AFAD) in a couple of years.

Turkey has applied an open door policy for Syrian inflows because it supposed that the conflicts have finished soon. Therefore, Turkey's open-door policy wasn't an migration policy, it could be named the humanitarian aid policy. Turkey needed a comprehensive migration policy after when the numbers became over 1 million in 2014 (GIGM, 2019). But this time there was a different problem. Policymaking needs a long process and it is not an event (Borkert and Penninx, 2011: 10). Even if Turkey has experience relating migratory and legal system peculiar to the migratory process, the experience, and legal system were insufficient. Taking time for deciding on migration policy and rapid increase in numbers of Syrian immigrants haven't matched each other and emerged important gaps. Besides, Turkey has been seen as a buffer zone against immigrant inflows towards the EU and having worked with some international organizations, like IOM and UNHCR, which want to naturalize and settling immigrations immediately in accordance with international human rights agreements. These organizations have powerful budgets that also make them policy actors relating to migration policies. In the last decade, IOM supplied important legal support coming to force the law on foreigners and international protection and empowering DGMM in migratory issues (IOM, 2018: 8). On the other side, Turkey promises to respect human rights as a result of international agreements being part. Moreover, deciding on policies rational, respecting human rights and taking into consideration Turkey's socioeconomical situation is impossible. The reasons made impossible to decide on migration policies stem from coercive externalities for Turkey. 
Turkey was committed humanitarian diplomacy in 2010s. International organizations like IOM and UNHCR, regional organizations like EU and international aggrements and tenets induced Turkey following humanitarian diplomacy. However, Turkey has been exposed unexpected great migratory flows along the decade.

Finally, the lack of solidarity of the international community on the results of Syria conflicts emerged in 2011 caused Turkey to deal with most of the burden alone because of geographical closeness. Even if the aim of migration policies deal with the problem caused migratory, this problem is so great and hinders Turkey deciding on reasonable migration policies. 
Turkey?

\section{REFERENCES}

Anderson, J. E. (2014). Public policymaking. Cengage Learning.

Borkert, M \& Penninx, R. (2011). Policymaking in the field of migration and integration in Europe: An introduction, in Migration policymaking in Europe: The dynamics of actors and contexts in past and present, Giovanna Zincone and others (Eds.), Amsterdam University Press, 7-21.

Bozkurt, K. (2016). Geri kabul ve vize serbestisi anlaşması, Türkiye Barolar Birliği Dergisi, 387-408.

Castles, S., De Haas, H., \& Miller, M. J. (2013). The age of migration: International population movements in the modern world. Macmillan International Higher Education.

Czaika, M., \& De Haas, H. (2013). The effectiveness of immigration policies. Population and Development Review, 39(3), 487-508.

Erdoğan, M. (2018). Suriyeliler barometresi: suriyelilerle uyum içerisinde yaşamın çerçevesi, İstanbul Bilgi Üniversitesi Yayınları.

Etzioni, A. (1967). Mixed-scanning: "A third" approach to decision-making. Public administration review, 385-392.

Filindra, A., \& Goodman, S. W. (2019). Studying public policy through immigration policy: Advances in theory and measurement. Policy Studies Journal, 47(3), 498-516.

https://www.goc.gov.tr/gecici-koruma5638 (Last Access: 30.10.2019).

https://www.unhcr.org/about-us.html (Last Access: 12.12.2019).

https://www.iom.int/about-iom (Last Access: 12.12.2019).

https://www.unhcr.org/tr/unhcr-turkiye-istatistikleri (Last Access: 14.12.2019).

https://multeciler.org.tr/turkiyedeki-suriyeli-sayisi/ (Last Access: 14.12.2019).

IOM (2018), MCOF: Göç krizi operasyonel çerçevesi: IOM Türkiye 2018-2019. 
İçduygu, A. \& Şimşek, D. (2017). Bargaining Over Refugees: Turkey's View, in Beyond the migration and asylum crisis: options and lessons for Europe, Ferrucciu Pastore (Ed.), Aspen Institute Italia, 85-91.

Minear, L. (2007). The craft of humanitarian diplomacy, in Humanitarian diplomacy: practitioners and their crafts, Larry Minear and Hazel Smith (Eds.), United Nations University Press, 5-36.

Natter, K. (2018). Rethinking immigration policy theory beyond 'Western liberal democracies'. Comparative migration studies, 6(4), 1-21.

Parkes, R. (2017). Nobody move! myths of the EU migration crisis, EU Institute for Security Studies.

Pastore, F. (2017). The European migration and asylum crisis as a long-term challenge, in Beyond the migration and asylum crisis: options and lessons for Europe, ferrucciu pastore (Ed.), Aspen Institute Italia, 10-58.

Sadık, G., \& Zorba, H. (2017). Humanitarian Diplomacy for Syrian Refugees and Turkey-EU Relations. Göç Araştırmaları Dergisi, 3(2), 10-39.

Sönmez, P. \& Kırık, H. (2017). Turkish-EU readmission agreement: a critique of eu-turkey migration dialogue, Güvenlik Stratejileri Dergisi, 13(25), 1-26.

UNHCR (2017). UNHCR's strategic directions: 2017-2021.

Uzun, E. (2016). Uluslararası hukuk çerçevesinde bmmyk'nın uluslararası mülteci yapısı, görevleri ve hukukunun gelişimindeki yeri, Göç Araştırmaları Dergisi, 2(2), 60-85.

Yıldız, A. G. (2016). The European Union's immigration policy: Managing migration in Turkey and Morocco. Springer. 


\section{GENIŞLETILMIŞ ÖZET}

\section{Giriş}

Kamu politikaları belirli bir süre içerisinde belirli bir problemi veya problemleri çözmeyi amaçlar. Kamu politikaları uygulanmadan önce birçok süreçlerden geçer. Politika seçeneklerinden birisini seçmek anlamına gelen karar verme, bu süreçlerden birisidir. Ancak kamu politika konusu göç ise bütün süreçler ve tabi olarak karar verme süreçleri de daha karmaşık hale gelir. Bu durum sadece sürecin aktörleri ile alakalı değil, göç politikalarının çok boyutlu olmasından kaynaklanır. Boyutlardan bazıları sağlık, işgücü piyasası, güvenlik ve ekonomik sistemlere ilişkindir. Böylece sektörel bazlı kamu politikası yapmak göç politikası yapmak anlamına gelse de gerçekte ayrıca göçe ilişkin somut bir kamu politikasına da ihtiyaç duyulur. Ortaya çıkan ikili durum göç politikalarına özgüdür. Bu yüzden bazı teorisyenler göç politikalarının kamu politikası olup olmadığını tartışmışlardır. Eğer bu süreçlere coğrafya da entegre edilirse kavram kargaşası ve teorik tartışma çok daha garipleşecek ve içinden çıkılması zor bir hal alacaktır. Bu makale ulusal göç politikalarının bazı dışsallıklarla sınırlandırıldığını iddia etmektedir. Bu sınırlandırıcılar o kadar güçlüdür ki ulusal hükümetlere göç politikası yapmaya neredeyse izin vermemektedir. Son on yılda, kitlesel göçlerle karşı karşıya kalan Türkiye, bu durumun en önemli örneklerinden birisidir. Bir yanda Avrupa Birliği gibi bazı uluslararası örgütler Türkiye'yi kendi politikalarının aracı haline getirmeye çalışırken, diğer yandan Türkiye, insancıl diploması politikası gibi ilkelere ve uluslararası hukuktan kaynaklanan ve Türkiye'nin de kabul ettiği insan hakları antlaşmaları ve insan hakları ile dolaylı yoldan ilişkili diğer antlaşmalar sadık kalmaya çalışmaktadır. Bütün bu sınırlayıcıların yanında bir de kamu politikaları literatüründe kabul edilen karar verme davranışlarına yönelik sınırlayıcılar bulunur. Karar verme literatürüne göre politika yapıcılar, karar verirlerken tam bir rasyonelliğe sahip değillerdir; çünkü tam rasyonellik için gerekli olan bütün bilgi ve tehlikelere sahip olamazlar. Bu yüzden karar vericiler, bu süreci gerçekleştirirken sınırlı sayıda seçeneği ve bilgiyi kullanırlar. $O$ halde karar vericiler, tam rasyonelliğe sahip değil, sınırlı rasyoneldir. Sonuç olarak bütün bu dışsal zorlayıcılar ve sınırıııklar ile hem insancıl politikanın izlendiği, hem devlet aklının gözetildiği bir göç politikası yapabilmek imkânsızdır. Türkiye'nin son on yıllık göç serüveni bu durumu kesin bir şekilde gözler önüne sermektedir.

\section{Metot}

Makalenin ana kaynakları uluslararası sözleşmeler, antlaşmalar, hükümet belgeleri ile politika belgeleri, Türkiye'nin göç ile alakalı yasal düzeni, uluslararası örgütlerin veya enstitülerin faaliyet raporları Türkiye'nin göç 
politikasına ilişkin akademik kitap ve makalelerdir. Bu kaynaklar betimleyici bir şekilde ele alınarak, Türkiye'nin göç politikası çözümlenmiştir. İnceleme nesnesi olarak Türkiye'nin son on yıldaki göç politikasını ele alan çalışmanın araştırma sorusu ise Türkiye için bir göç politikasının mümkün olup olmadığı sorusudur. Kaynakların nesnel olarak değerlendirilemeye çalışıldığı makalede, göç politikalarının mümkünlüğü hem göçmenler için insancıl bir hayat yaşayabilecekleri imkanların sağlanması hem de Türkiye'nin kendi politikalarına kendisinin karar verebilmesidir. Bundan dolayı dışsal sınırlandırıcılar kamu politikalarını imkânsız yapar olarak tanımlanmıştır.

\section{Bulgular}

Türkiye şu anda 4 milyonun üzerinde göçmenin yaşadığı bir ülke konumundadır. Bunların çok büyük bir oranı son on yıl içerisinde Türkiye'ye giriş yapmıştır. Bu durumda temel sebep Suriye'deki iç savaş olsa da önemli sayıda Afgan göçmene de sahiptir. Özellikle Suriyeli göçmenlerin açık kapı politikası nedeniyle ülkeye giriş yapsalar da, böyle bir politikanın izlenmediği Afgan göçmenler yoluyla görülmektedir. Bu durum göç politikası konusunda sınır güvenliği konusunda problemler olduğunu göstermektedir. Kısa sürede bu kadar büyük sayılarda göçmenin gelmesi, ortada göç politikasının yanında bir acil durumun varlığını göstermektedir. Son olarak göçmenlerin asıl ulaşmak istediği hedef konum olan Avrupa, Türkiye'yi Avrupa Birliği'nin tampon bölgesi olarak kullanmaya çalışmakta olduğu söylenmelidir.

\section{Sonuç ve Tartışma}

Türkiye için rasyonel bir göç politikasının imkansızlığını iddia eden bu çalışmaya göre, göç politikalarını imkansızlaştıran dışsallıklar da birbirleriyle çelişmektedir. Bu durum Geri Kabul Antlaşması'nda açık olarak görülmektedir. Anlaşma'nın gerekleri Avrupa Birliği'nin Türkiye'yi tampon bölge olarak kullanma arzusunun bir gereği olarak ortadayken, aynı zamanda uluslararası hukuk anlamında geri gönderme yasağına, bu metindeki adlandırmasıyla insancıl diplomasi politikasına ve insan haklarına aykırılık teşkil eder.

Uluslararası dayanışmanın eksikliğinden dolayı Türkiye, özellikle Suriye iç savaşının göçmen akışını büyük oranla tek başına kabul etmiştir. Özellikle coğrafi yakınlık bu akıştan en çok etkilenen ülke olmasının asıl sebebidir. Göç politikalarının amacı göçün sebep olduğu problemler ile mücadele etmek olsa da, bu problem Türkiye için o kadar büyüktür ki rasyonel olarak bir göç politikası üzerinde karar vermeyi engellemektedir. Türkiye, bir yandan Avrupa Birliği gibi kendisini politika aracı olarak kullanmaya çalışan örgütler ile diğer yandan uluslararası hukuktan kaynaklanan yükümlülükler, başka bir taraftan insancıl diplomasinin gerekleri arasına sıkışmış durumdadır. $\mathrm{Bu}$ durumda hem 
göçmenlere insancıl bir hayat olanakları verebilecek kamu politikalarından yoksundur hem de devlet aklı olarak ifade edilebilecek ulusal menfaatleri koruyabilecek göç politikalarından yoksundur.

Tarihsel olaylar deneysel sorgulamalara tabi tutulamaz; fakat bu olayları analiz eden araştırmacılar tarihsel kronolojide kendi araştırmaları sonucunda sebepsonuç ilişkisi kurmaya çalışabilir. Bu çalışma açısından böyle bir sorgulama yapıldığında ilk akla gelen soru, acaba Suriye iç savaşı yaşanmasaydı, Türkiye'nin göç politikasının imkânı üzerine bir çalışma yapılıp yapılamayacağıdır. Gerçekten de Türkiye açııından en dikkate değer yorum göç politikalarıı imkânsızlaştıranın kitlesel göçe maruz kalan kişilerin çokluğu olduğu ileri sürülebilir. 